$118 / 51960$

\title{
Measurement Uncertainty of Silicone \\ Oil Leakage Testing
}

W. E. Holland

KCP-613-4476

Published November 1991

- Prepared for the United States Department of Energy Under Contract Number DE-AC04-76-DP00613.

\section{Allied-Sigaal Aorospace Company}




\section{DISCLAIMER}

This report was prepared as an account of work sponsored by an agency of the Urited States Government. Neither the United States Government nor any agency thereof, nor any of their employees, makes any w: urranty, express or implied, or assumes any legal liability or responsibility for the accuracy, complriteness, or usefulness of any information, apparatus, product, or process disclosed, or represents; that its use would not infringe privately owned rights. Reference herein to anf specific commercial product, process, or service by trade name, trademark, manufacturer, or otherwise, does not necessarily constitute or imply its endorsement, recommendation, or favoring by the United States Government or any agency thereof. The views and opinions of authors expressed herein do not necessarily state or refiect those of the United States Government or any
agency thereof.

Printed in the United States of America

This report has been reproduced from the best available copy.

Available to DOE and DOE contractors from the Office of Scientific and Technical Information,

P. O. Box 62, Oak Ridge, Tennessee 37831; prices available from (615) 576-8401, FTS 626-8401.

Available to the public from the National Technical Information Service, U. S. Department of Commerce, 5285 Port Roy.d Fd., Springfield, Virginia 22161. 
KCP $--613-4476$

Distribution DE92 003678

\section{MEASUREMENT UNCERTAINTY OF SILICONE} OIL LEAKAGE TESTING

W. E. Holland

Published November 1991

Technical Communications ${ }^{\circ}$

Kansas City Division 
MEASUREMENT UNCERTAINTY OF SILICONE OIL LEAKAGE TESTING

KCP-613-4476, Published November 1991

Prepared by W. E. Holland

An evaluation has been performed to determine the uncertainty of silicone tracer fluid leakage measurements for an environmental sensing device. The units are tested with an instrument which can measure silicone tracer fluid vapor by the gas chromatography method. An analysis has shown that the measurement uncertainty can be maintained at $\pm 20 \%$ when the volumes used in the procedure are held to a given set of tolerances.

BB 
CONTENTS

Section

Page

SUMMARY

DISCUSSION

SCOPE AND PURPOSE

ACTIVITY

The Testing Process

Mathematical Simulation . . . . . . . . . 13

Proposed Tolerances . . . . . . . . . . . 15

Total Uncertainty of the Process . . . . . . . 15 ACCOMPLISHMENTS

APPENDICES

A. UNCERTAINTY SUMMARY . . . . . . . . . . . 17

B. STATISTICAL DATA . . . . . . . . . . . 21

C. UNCERTAINTY IN CONTROL SAMPLE VOLUME MEASUREMENTS .................... 29

D. DIFFERENCE IN VOLUME BETWEEN CONTROL SAMPLES AND SWITCHES . . . . . . . . . . . 33

E. MEASUREMENT OF SAMPLE VOLUME AND EVACUATED TUBE VOLUME 


\section{ILLUSTRATION}

Figure

Page

1

Silicone Tracer Fluid Measurement Volumes

12 


\section{SUMMARY}

A mathematical simulation of the silicone tracer fluid leak testing procedures for an environmental sensing device showed that the leak rate criterion could be modeled by a simple equation involving five volumes that required control (certification). An uncertainty source evaluation was implemented to $l i s t$ and quantify random and systematic uncertainty sources for each volume. Where sufficient numbers of a type of volume were available, a standard deviation of the population was calculated to allow for setting a tolerance which would encompass most replacement items. A set of practical tolerances for the volumes was recommended, and the total uncertainty of the measurement process (using these tolerances) was calculated. 


\section{DISCUSSION}

\section{SCOPE AND PURPOSE}

Metrology at Allied-Signal Inc., Kansas City Division (KCD) has been requested to evaluate the uncertainty involved in silicone oil leak testing.

Silicone oil is added to an environmental sensing device (ESD) as a damping material. It is necessary to test for leakage because leaking oil could contaminate other components. To speed the testing, low viscosity silicone oil $(0.65 \mathrm{cs}$ tracer fluid) is mixed with the damping material. The tracer fluid will diffuse through a leak more readily than the high viscosity oil so that leakage can be detected more rapidly.

\section{ACTIVITY}

\section{The Testing Process}

The ESD units are loaded into containers called "test fixtures," and the test fixtures are then heated to $75^{\circ} \mathrm{C}$. The $0.65 \mathrm{cs}$ tracer fluid boils at $60^{\circ} \mathrm{C}$ so that any fluid leaking from the units should diffuse readily into the test fixtures. After the test fixture has been heated for 2 hours minimum, a small sample of gas is removed and tested for tracer fluid using a gas chromatograph.

Calibration of the gas chromatograph is accomplished by preparing a "known" sample of the tracer fluid vapor in a test fixture and comparing the response of the gas chromatograph when injecting the known amount and the test sample. The test fixtures used for preparing the known samples are called "reference" fixtures.

The known sample is prepared in several steps as shown in Figure 1. First, $3 \mu \mathrm{L}$ of silicone tracer fluid are measured with a 5- $\mu L$ syringe and injected into a clean nitrogen-filled 21-L flask. The flask is then agitated and allowed to stabilize. The flask contains 15 solid, 3/8-in.-diareter, Teflon balls which help to distribute the fluid vapor uniformly in the flask when it is agitated. Next, approximately $1 \mathrm{~mL}$ of silicone tracer fluid vapor is withdrawn from the flask using a gastight $1-\mathrm{mL}$ syringe. The plunger of the syringe is retracted to the stop so that a repeatable amount can be extracted. The vapor in the syringe is injected into a sealed, evacuated reference fixture containing control samples, and then the reference fixture is filled with air zero up to atmospheric pressure and stored at $75^{\circ} \mathrm{C}$ for a minimum of two hours. The known sample is now ready to be introduced into the sampler of the gas chromatograph. 




Figure 1. Silicone Tracer Fluid Measurement Volumes 
The sampler of the gas chromatograph is evacuated before a sample is drawn from a fixture containing either the known sample or the parts to be tested. After the fixture is connected, the pressures in the fixture and the sampler are allowed to equilibrate, and then the fixture is removed. However, only a portion of the amount drawn into the sampler-the amount in the sample loop--is flushed into the gas chromatograph.

\section{Mathematical Simulation}

Symbols used in the mathematical analysis of uncertainty are defined below. Refer to Figure 1 for additional explanation.

$\mathrm{V} 1$ = Volume dispensed by the $5 \cdot 0-\mu \mathrm{L}$ syringe from the $3.0-\mu \mathrm{L}$ mark.

V2 = Volume of the 21-L flask minus volume of balls.

$\mathrm{V} 3=$ Volume of the $1-\mathrm{mL}$ syringe at the stop (approximately $1.07 \mathrm{~mL}$ ).

V4 = Volume of the reference fixture minus volume of the control samples (approximately $1 \overline{00 \mathrm{~mL}}$ net).

W4 = Volume of the test fixture minus volume of the switches.

$\mathrm{V} 5$ = Volume of the sample loop.

V6 = Volume in evacuated lines (exclusive of sample loop).

Then the concentration of silicone tracer fluid in the flask is

$\mathrm{C} 2=$ Concentration in $\mathrm{flask}=\mathrm{V} 1 / \mathrm{V} 2$,

and the concentration in the reference fixture is

$$
\begin{aligned}
\mathrm{C}_{4} & =\text { Concentration in reference fixture }=\mathrm{V} 3(\mathrm{C} 2) / \mathrm{V} 4 \\
& =\mathrm{V} 3(\mathrm{~V} 1 / \mathrm{V} 2) / \mathrm{V} 4 \\
& =\frac{\mathrm{V} 1 \cdot \mathrm{V} 3}{\mathrm{~V} 2 \cdot \mathrm{V} 4} .
\end{aligned}
$$

The volume of silicone tracer fluid A introduced into the sample loop from the reference fixture is

$$
A=V_{5}\left(\frac{V 1 \cdot V 3}{V 2(V 4+V 5+V 6)}\right)
$$


$C$

Here the term $\mathrm{V} 4+\mathrm{V} 5+\mathrm{V} 6$ has been used in the denominator because the concentration is changed slightly when the volume $\mathrm{V} 5+\mathrm{V} 6$ is added to the volume containing the silicone tracer fluid while the sample loop is being filled.

Nexc, it is necessary to find an equation for the volume $S$ of silicone tracer fluid in the sample loop when a volume $X$ of silicone tracer fluid is leaked into the test fixture W4. By comparison to the above equation, the volume $S$ is

$$
\mathrm{S}=\mathrm{V5}\left(\frac{\mathrm{X}}{\mathrm{W} 4+\mathrm{V} 5+\mathrm{V} 6}\right)
$$

where,

$$
\begin{aligned}
X & =\text { Volume of silicone tracer fluid leaked from switches } \\
\text { into test fixture } & \\
& =\text { leak rate } x \text { time }=R \cdot T,
\end{aligned}
$$

or

$$
\mathrm{S}=\mathrm{V} 5 \frac{\mathrm{X}}{\left(\mathrm{W}_{4}+\mathrm{V} 5+\mathrm{V} 6\right)}=\mathrm{V} 5 \frac{\mathrm{R} \cdot \mathrm{T}}{(\mathrm{W} 4+\mathrm{V} 5+\mathrm{V} 6)}
$$

The criterion for switch acceptance is $\mathrm{S} \leq \mathrm{A}$

or

$$
\frac{\mathrm{V} 5 \cdot \mathrm{R} \cdot \mathrm{T}}{(\mathrm{W} 4+\mathrm{V} 5+\mathrm{V} 6)} \leq \frac{\mathrm{V} 1 \cdot \mathrm{V} 3 \cdot \mathrm{V} 5}{\mathrm{~V} 2(\mathrm{~V} 4+\mathrm{V} 5+\mathrm{V} 6)}
$$

This criterion can be expressed in terms of the leak rate as

$$
\mathrm{R} \leq \frac{\mathrm{V} 1 \cdot \mathrm{V} 3 \cdot \mathrm{V} 5}{\mathrm{~V} 2(\mathrm{~V} 4+\mathrm{V} 5+\mathrm{V} 6)} \frac{(\mathrm{W} 4+\mathrm{V} 5+\mathrm{V} 6)}{\mathrm{V} 5 \cdot \mathrm{T}}=\frac{\mathrm{V} 1 \cdot \mathrm{V} 3}{\mathrm{~V} 2 \cdot \mathrm{T}} \frac{(\mathrm{W} 4+\mathrm{V} 5+\mathrm{V} 6)}{(\mathrm{V} 4+\mathrm{V} 5+\mathrm{V} 6)}
$$

The uncertainty in the leak rate measurement can be specified if the uncertainty in V1, V2, V3, V4, W4, and $\mathrm{T}$ can be determined. It is not necessary to calibrate volumes $V 5$ and $V 6$ because they are small compared to $\mathrm{V}_{4}$ and $\mathrm{W} 4$ and have constant values; an initial measurement will suffice.

The uncertainties of the variables imply a minimum and maximum value that each variable can attain. Likewise, the measured value of $R$ can attain a range of values resulting from varying values of the variables. The equation for $R$ can be used to determine this range. The minimum value of $R$ is achieved when each term in the numerator has its minimum viriue and each term 
in the denominator has its maximum value. Likewise, the maximum value of $R$ is achieved when each term in the numerator assumes its maximum value and each term in the denominator reaches its minimum value.

The uncertainties of the variables V1, V2, V3, V4, and W4 have been analyzed, and a summary of uncertainty sources and amounts is shown in Appendix A. Statistical data to support this analysis is given in Appendix B. An evaluation of the uncertainty involved in certifying the volume of the control samples is included in Appendix C, and an evaluation of the difference in volume between control samples and switches is presented in Appendix D. Measurements of V5 and V6 are described in Appendix $E$.

\section{Proposed Tolerances}

Tolerances for the volumes based on the uncertainty analysis are proposed below.

\begin{tabular}{|c|c|c|c|}
\hline Volume & Proposed Tolerance & Minimum (mL) & Maximum (mL) \\
\hline $\begin{array}{l}\text { V1 } \\
\text { V2 } \\
\text { V3 } \\
\text { V4 } \\
\text { W4 }\end{array}$ & $\begin{array}{l}(3.12 \pm 0.20) \times 10^{-3} \mathrm{~mL} \\
21000 \pm 200 \mathrm{~mL} \\
1.0655 \pm 0.01 \mathrm{~mL} . \\
98.1 \pm 5 \mathrm{~mL} \\
100.1 \pm 5 \mathrm{~mL}\end{array}$ & $\begin{array}{l}2.92 \times 10^{-3} \\
20800 \\
1.0555 \\
93.1 \\
95.1\end{array}$ & $\begin{array}{l}3.32 \times 10^{-3} \\
21200 \\
1.0755 \\
103.1 \\
105.1\end{array}$ \\
\hline
\end{tabular}

\section{Total Uncertainty of the Process}

The resulting minimum, maximum, and nominal values of the leak rate simulated by the calibration process for a one-hour test are given below.

$$
\begin{aligned}
& R=\frac{2.92 \times 10^{-3} \times 1.0555(95.1+5.24) \mathrm{mL} / \mathrm{s}}{21200 \times 3600(103.1+5.24)}=3.74 \times 10^{-11} \mathrm{~mL} / \mathrm{s} \text { (min.) } \\
& R=\frac{3.32 \times 10^{-3} \times 1.0755(105.1+5.24) \mathrm{mL} / \mathrm{s}}{20800 \times 3600(93.1+5.24)}=5.35 \times 10^{-11} \mathrm{~mL} / \mathrm{s}(\max .) \\
& R=\frac{3.12 \times 10^{-3} \times 1.0655(100.1+5.24) \mathrm{mL} / \mathrm{s}}{21000 \times 3600(98.1+5.24)}=4.48 \times 10^{-11} \mathrm{~mL} / \mathrm{s} \text { (nom.) }
\end{aligned}
$$

These values yield an uncertainty range on the leak rate. measurement of $\pm 20 \%$.

To determine the leak rate for longer tests, divide the above values by the number of hours of testing. For example, for a two-hour test, the leak rate simulated by the calibration process would be $2.24 \times 10^{-11} \mathrm{~mL} / \mathrm{s}$. 
The portion of the uncertainty resulting from the uncertainty in each volume is given below:

\begin{tabular}{cr} 
& \multicolumn{2}{c}{ Percent } \\
Volume & Total Unce \\
\cline { 2 - 2 } V1 & $33 \%$ \\
V2 & $5 \%$ \\
V3 & $5 \%$ \\
V4 & $28 \%$ \\
W4 & $28 \%$
\end{tabular}

Because V1, V4, and W4 provide the largest contributions to the total uncertainty, any attempts to reduce the uncertainty

further should be focused on these variables.

\section{ACCOMPLISHMENTS}

The measurement uncertainty of silicone tracer fluid leakage testing has been quantified for the first time. Results of the evaluation show that an uncertainty of $\pm 20 \%$ can be achieved at leak rates as small as $2.24 \times 10^{-1} \mathrm{~mL} / \mathrm{s}$ for a two-hour test. 
Appendix A

UNCERTAINTY SUMMARY 


\section{UNCERTAINTY SUMMARY}

MEASUREMENT UNC. SOURCES

MEAS. UNC. AMOUNT

PROPOSED TOLERANCE

$\underline{5.0 \mu L \text { Syringe (V1) }}$

$0.00312 \pm n .00020 \mathrm{~mL}$

Systematic

$$
\begin{array}{ll}
\text { Error at } 3.0 \mu \mathrm{L} & +0.000123,+0.000115, \\
& +0.000039,+0.000208 \mathrm{~mL}
\end{array}
$$

Random

$$
\begin{aligned}
& \text { Dispensing Variations ( } 16 \text { samples, 3SD) } \pm 0.000083 \mathrm{~mL} \\
& \text { Balance Uncertainty } \\
& \pm 0.00004 \mathrm{~mL} \\
& \text { Total } \pm 0.000123 \mathrm{~mL}
\end{aligned}
$$

\section{L Reference Flask (V2)}

$21000 \pm 200 \mathrm{~mL}$

Systematic

Variation in Construction ( 3 samples) $+168,-69,+152 \mathrm{~mL}$

Random

$$
\begin{array}{ll}
\text { Balance Uncertainty (Full, 24713g) } & \pm 2 \mathrm{~mL} \\
\text { Balance Uncertainty (Empty, 3603g) } & \pm 2 \mathrm{~mL} \\
\text { Filling Variation } & \pm 1 \mathrm{~mL}
\end{array}
$$

$1 \mathrm{~mL}$ Syringe (V3)

Systematic

$$
\text { Difference from } 1.0000 \mathrm{~mL} \text { ( } 4 \text { samples, avg.) } 0.0670 \mathrm{~mL}
$$

Random

$$
\begin{array}{lr}
\text { Air Bubbles on Teflon } & \pm 0.0010 \mathrm{~mL} \\
\text { Variation from Avg. Volume (1.0670 mL, 3SD) } & \pm 0.0047 \mathrm{~mL} \\
\text { Dispensing Variation (16 samples, 3SD) } & \pm 0.0006 \mathrm{~mL} \\
\text { Balance Uncertainty (Ful1, 3.36g) } & \pm 0.0001 \mathrm{~mL} \\
\text { Balance Uncertainty (Empty, 2.28g) } & \pm 0.0001 \mathrm{~mL} \\
& \pm 0.0065 \mathrm{~mL} \\
& \pm \text { Total } \\
& \pm \text { Estimated }
\end{array}
$$


UNCERTAINTY SUMMARY (Cuicinued)

MEASUREMENT UNC. SOURCES

MEAS. UNC. AMOUNT

PROPOSED TOLERANCE

Reference Fixture (V4) and Test Fixture (W4) Reference (V4) $98.1 \pm 5.0 \mathrm{~mL}$ Test (W4) $100.1 \pm 5.0 \mathrm{~mL}$

\section{Container}

Random

$$
\begin{aligned}
& \text { Balance Uncertainty (Full, 830g) } \\
& \text { Balance Uncertainty (Empty, 680g) } \\
& \text { Filling Error (bubbles, etc.) } \\
& \text { Part-to-Part Variation (39 samples, 3SD) } \\
& \pm 0.00299 \mathrm{~mL} \\
& \pm 0.00254 \mathrm{~mL} \\
& \pm 0.01 \mathrm{~mL} * \\
& \pm 5.34 \mathrm{~mL}
\end{aligned}
$$

\section{Control Samples}

Systematic

$$
\text { Vol. Difference (Controls vs. Switches) } \quad+1.952 \mathrm{~mL}
$$

Random

$$
\begin{array}{ll}
\begin{array}{l}
\text { Uncertainty in Density and Weighing } \\
\text { Part-to-Part Variation (8 samples, 3SD) }
\end{array} & \pm 0.249 \mathrm{~mL} \\
& \pm 0.60 \mathrm{~mL} \\
\text { Total } & \pm 0.849 \mathrm{~mL} \\
& \\
& \pm \text { Estimated }
\end{array}
$$


Appendix B

STATISTICAL DATA 


\section{STATISTICAL DATA}

Fifty volumes were calibrated for the leak testing program. Each was given a Calibration Control Number (CCN).

The syringes, flasks, reference fixtures, and test fixtures were calibrated with water. The 5.0- $\mu$ L syringes were calibrated by weighing the amount of water dispensed from the 3.0- $\mu \mathrm{L}$ mark, and the $1.0-\mathrm{mL}$ syringes were calibrated by weighing the amount of water dispensed when the syringes were filled to the stop and emptied. The flasks, reference fixtures, and test fixtures were calibrated by weighing them empty and filled with water.

Calibration of the control samples is described in Appendix $\mathrm{C}$. Data from the calibrations are given below.

$\underline{5.0 \mu 1 \text { Syringe (V1) }}$

CCN 20997

$\begin{array}{ll}\text { Trial Volume } & \text { Dev. from Avg. } \\ & \left(10^{-3} \mathrm{~mL}\right)\end{array}$

13.123

$2 \quad 3.107$

$3 \quad 3.134$

$4 \quad \underline{3.129}$

Avg. $\quad 3.123$
CCN 20998

Vol ume Dev. from Avg.
$\left(10^{-3} \mathrm{~mL}\right)$

$3.099 \quad-0.016$

$3.132 \quad 0.017$

$3.050 \quad-0.065$

$\underline{3.179} \quad 0.064$

3.115
CCN 20999

Trial Volume Dev. from Avg. $\left(10^{-3} \mathrm{~mL}\right) \quad\left(10^{-3} \mathrm{~mL}\right)$

$\begin{array}{lll}1 & 3.030 & -0.009\end{array}$

$2 \quad 3.016$

$3 \quad 3.072$

$4 \quad \underline{3.037}$

Avg .

3.039
$\underline{\operatorname{CCN} 21000}$

Volume Dev. f r rom Avg. $\left(10^{-3} \mathrm{~mL}\right) \quad\left(10^{-3} \mathrm{~mL}\right)$

$\begin{array}{ll}3.180 & -0.028 \\ 3.225 & 0.017 \\ 3.213 & 0.005 \\ 3.214 & 0.006\end{array}$

3.208 
$\underline{\mathrm{CCN}}$

20997

20998

20999

21000 $\frac{\text { Deviation from } 3.000 \times 10^{-3} \mathrm{~mL}}{\left(10^{-3} \mathrm{~mL}\right)}$

3.123

3.115

3.039

3.208
Dev. from Avg. $\left(10^{-3} \mathrm{~mL}\right)$

$$
\begin{array}{r}
0.002 \\
-0.006 \\
-0.082 \\
0.087
\end{array}
$$

Standard Deviation ( 16 trials) $=0.028 \times 10^{-3} \mathrm{~mL}$

3 Standard Deviations $=0.083 \times 10^{-3} \mathrm{~mL}$

\section{L Reference Flask (V2)}

\section{$\underline{\mathrm{CCN}}$}

20943

20944

21089

$1 \mathrm{~mL}$ Syringe (V3)

\section{CCN 21051}

\begin{tabular}{llr} 
Trial & $\begin{array}{l}\text { Volume at } \\
\text { Stop (mL) }\end{array}$ & $\begin{array}{r}\text { Dev. from Avg. } \\
\text { (mL) }\end{array}$ \\
\cline { 3 - 3 } 1 & 1.0679 & -0.0001 \\
2 & 1.0680 & 0.0000 \\
3 & 1.0679 & -0.0001 \\
4 & $\underline{1.0681}$ & 0.0001 \\
Avg. & 1.0680 &
\end{tabular}

Dev. from 21 L (mL)

$$
\begin{aligned}
& 21168 \\
& 20931 \\
& 21152
\end{aligned}
$$

$\underline{\operatorname{CCN} 21052}$

Volume at Dev. from Avg. Stop (mL) $(\mathrm{mL})$

\begin{tabular}{lr}
1.0652 & 0.0001 \\
1.0651 & 0.0000 \\
1.0647 & -0.0004 \\
1.0655 & 0.0004 \\
\hline
\end{tabular}

1.0651 


\section{CCN 21053}

\begin{tabular}{llr} 
Trial & $\begin{array}{l}\text { Volume at } \\
\text { Stop (mL) }\end{array}$ & $\begin{array}{r}\text { Dev. from Avg. } \\
\text { (mL) }\end{array}$ \\
\cline { 3 - 3 } 1 & 1.0658 & -0.0001 \\
2 & 1.0659 & 0.0000 \\
3 & 1.0659 & 0.0000 \\
4 & $\underline{1.0659}$ & 0.0000 \\
Avg. & 1.0659 &
\end{tabular}

Volume at

CCN

21051

21052

21053

20982

\section{CCN 20982}

Volume at Dev. from Avg.

Stop (mL) $(\mathrm{mL})$

\begin{tabular}{lr}
1.0691 & 0.0001 \\
1.0688 & -0.0002 \\
1.0689 & -0.0001 \\
1.0691 & .0 .00001 \\
\hline
\end{tabular}

1.0690

Standard Deviation (16 trials) $=0.0002 \mathrm{~mL}$ 3 Standard Deviations $=0.0006 \mathrm{~mL}$

Dev. from Avg. (mL)

0.0010

$-0.0019$

$-0.0011$

0.0020 
Reference Fixture (V4) and Test Fixture (W4)

\begin{tabular}{|c|c|c|c|}
\hline$\underline{\mathrm{CCN}}$ & Volume (mL) & $\frac{\text { Dev. from } 141.8 \mathrm{~mL}}{(\mathrm{~mL})}$ & $\frac{\text { Dev. from Avg. }}{(\mathrm{mL})}$ \\
\hline  & $\begin{array}{l}144.63 \\
140.44 \\
141.74 \\
137.98 \\
140.90 \\
141.91 \\
142.05 \\
139.94 \\
140.09 \\
144.75 \\
142.79 \\
142.54 \\
140.65 \\
140.22 \\
143.38 \\
145.36 \\
139.40 \\
140.52 \\
143.11 \\
138.29 \\
140.26 \\
140.42 \\
140.31 \\
143.39 \\
141.99 \\
141.53 \\
141.92 \\
142.52 \\
140.83 \\
142.02 \\
139.51 \\
140.99 \\
138.64 \\
144.47 \\
140.55 \\
143.27 \\
143.18 \\
140.41 \\
143.48\end{array}$ & $\begin{array}{r}2.81 \\
-1.38 \\
-0.08 \\
-3.84 \\
-0.92 \\
0.09 \\
0.23 \\
-1.88 \\
-1.73 \\
2.93 \\
0.97 \\
0.72 \\
-1.17 \\
-1.60 \\
1.56 \\
3.54 \\
-2.42 \\
-1.30 \\
1.29 \\
-3.53 \\
-1.56 \\
-1.40 \\
-1.51 \\
1.57 \\
0.17 \\
-0.29 \\
0.10 \\
0.70 \\
-0.99 \\
0.20 \\
-2.31 \\
-0.83 \\
-3.18 \\
2.65 \\
-1.27 \\
1.45 \\
1.36 \\
-1.41 \\
1.66\end{array}$ & $\begin{array}{r}3.08 \\
-1.11 \\
0.19 \\
-3.57 \\
-0.65 \\
0.36 \\
0.50 \\
-1.61 \\
-1.46 \\
3.20 \\
1.24 \\
0.99 \\
-0.90 \\
-1.33 \\
1.83 \\
3.81 \\
-2.15 \\
-1.03 \\
1.56 \\
-3.26 \\
-1.29 \\
-1.13 \\
-1.24 \\
1.84 \\
0.44 \\
-0.02 \\
0.37 \\
0.97 \\
-0.72 \\
0.47 \\
-2.04 \\
-0.56 \\
-2.91 \\
2.92 \\
-1.00 \\
1.72 \\
1.63 \\
-1.14 \\
1.93\end{array}$ \\
\hline Avg. & 141.55 & & \\
\hline
\end{tabular}




\section{Control Samples}

$\begin{array}{ll}\text { CCN } & \begin{array}{l}\text { Volume of Control } \\ \text { Samples (mL) }\end{array}\end{array}$

Dev. from Avg. (mL)

20927

20928

20930

20931

20934

20935

20936

20937

43.33

43.37

43.33

43.32

43.66

43.74

43.78

43.71

$-0.20$

$-0.16$

$-0.20$

$-0.21$

0.13

0.21

0.25

0.18

Avg.

43.53

Standard Deviation of Control Samples ( 8 samples) $=0.20 \mathrm{~mL}$

3 Standard Deviations $=0.60 \mathrm{~mL}$

Net $*$ of Average Volumes $=141.55 \mathrm{~mL}-43.53 \mathrm{~mL}=98.02 \mathrm{~mL}$

"Average volume of fixture less average volume of control samples. 
Appendix C

UNCERTAINTY IN CONTROL SAMPLE VOLUME MEASUREMENTS 
c

UNCERTAINTY IN CONTROL SAMPLE VOLUME MEASUREMENTS

Because some of the control samples have irregular shapes (threads, etc.), the best way to determine their volume is to measure their mass and density and then to calculate their volume using the equation $V=$ mass/density. This will also ease the task of recalibration because the volume can be determined regardless of surface damage to the parts.

Density of control samples was determined by measuring the mass $m$ and volume $v$ of four specially selected blocks and then calculating the density using the formula $\mathrm{d}=\mathrm{m} / \mathrm{v}$. The blocks were selected for uniformity and parallelism. Volume of the selected blocks was determined by measuring the length, width, and height of the blocks.

Uncertainty in the length, width and height measurements was $\pm 0.003 \mathrm{~cm}$, and this yielded an uncertainty of $\pm 0.029 \mathrm{~cm}^{3}$ in the block volume measurements, as calculated by the equation:

$$
\begin{aligned}
& v=1 \cdot w \cdot h=(3.187 \pm 0.003) \times(1.266 \pm 0.003) \times \\
&(1.266 \pm 0.003) \mathrm{cm}^{3} \\
&=5.108 \pm 0.029 \mathrm{~cm}^{3} .
\end{aligned}
$$

The uncertainty in the weighing of a block was $0.000519 \mathrm{~g}$, so that the uncertainty in the density was $\pm 0.044 \mathrm{~g} / \mathrm{cm}^{3}$ as calculated by the formula:

$\mathrm{d}=\frac{\mathrm{m}}{\mathrm{v}}=\frac{39.528 \pm 0.0005 \mathrm{~g}}{5.108 \pm 0.029 \mathrm{~cm}^{3}}=7.7386 \pm 0.044 \mathrm{~g} / \mathrm{cm}^{3}$ 
Data for the blocks used for the density determinations are presented below.

Dimensions

\begin{tabular}{|c|c|c|c|c|c|}
\hline $\begin{array}{l}\text { Length } \\
\text { (in.) } \\
\end{array}$ & $\begin{array}{l}\text { Width } \\
\text { (in.) } \\
\end{array}$ & $\begin{array}{l}\text { Height } \\
\text { (in.) } \\
\end{array}$ & $\begin{array}{l}\text { Vol ume } \\
\left(\mathrm{cm}^{3}\right)\end{array}$ & $\begin{array}{l}\text { Weight } \\
(g)\end{array}$ & $\begin{array}{l}\text { Density } \\
\left(\mathrm{g} / \mathrm{cm}^{3}\right)\end{array}$ \\
\hline $\begin{array}{l}1.2550 \\
1.2575 \\
1.2515 \\
1.2550\end{array}$ & $\begin{array}{l}0.5000 \\
0.4975 \\
0.4975 \\
0.4976\end{array}$ & $\begin{array}{l}0.4997 \\
0.4983 \\
0.4988 \\
0.4990\end{array}$ & $\begin{array}{l}5.13836 \\
5.10850 \\
5.08922 \\
5.10653\end{array}$ & $\begin{array}{l}39.73183 \\
39.51283 \\
39.36226 \\
39.59088\end{array}$ & $\begin{array}{l}7.7324 \\
7.7347 \\
7.7344 \\
7.7530 \\
\end{array}$ \\
\hline & & & & Average & 7.7386 \\
\hline
\end{tabular}

The uncertainty in the control samples in a reference fixture (average weight $338 \mathrm{~g}$, average density $7.7386 \mathrm{~g} / \mathrm{cm}^{3}$ ) was calculated to be $\pm 0.249 \mathrm{~cm}^{3}$ from the formula:

$\mathrm{V}=\frac{\text { mass }}{\text { density }}=\frac{338 \pm 0.0015 \mathrm{~g}}{7.7386 \pm 0.044 \mathrm{~g} / \mathrm{cm}^{3}}=43.677 \pm 0.249 \mathrm{~g} / \mathrm{cm}^{3}$ 
Appendix D

DIFFERENCE IN VOLUME BETWEEN CONTROL SAMPLES AND SWITCHES 


\section{APPEND!X D}

DIFFERENCE iN VOLUME BetweEN CONTROL SAMPLES AND SWITCHES

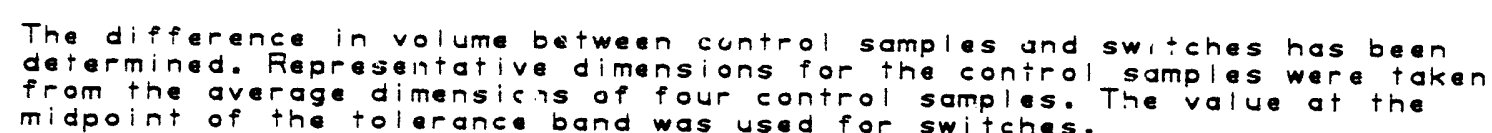
from the average dimensicis of four control samples. The valu at the midpoint of the tolerance band was used for switches.
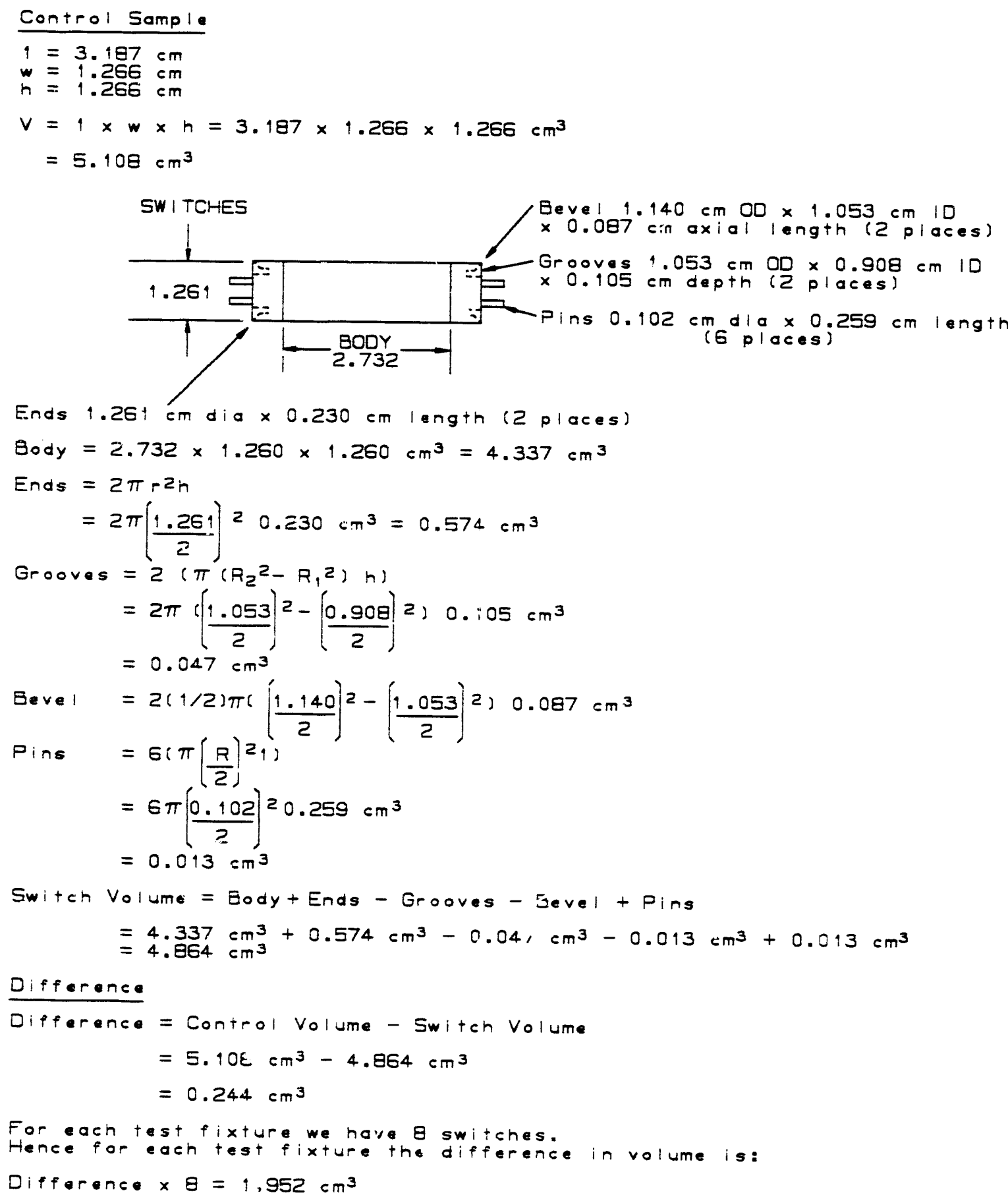
Appendix E

MEASUREMENT OF SAMPLE VOLUME AND EVACUATED TUBE VOLUME 
The volume of the sample loop was measured prior to installing it in the sampler by filling the sample loop tubing with water and weighing. The weight of the filled tube was subtracted from the dry weight to determine the weight of the water in the tube. This was multiplied by the appropriate density factor to determine the volume, $1.0074 \mathrm{~mL}$.

The volume of the evacuated portion of the sampler was measured with a volumeter and was found to be $5.24 \mathrm{~mL}$. Hence, the volume of the evacuated portion of the sampler exclusive of the sample loop was $4.23 \mathrm{~mL}$. 

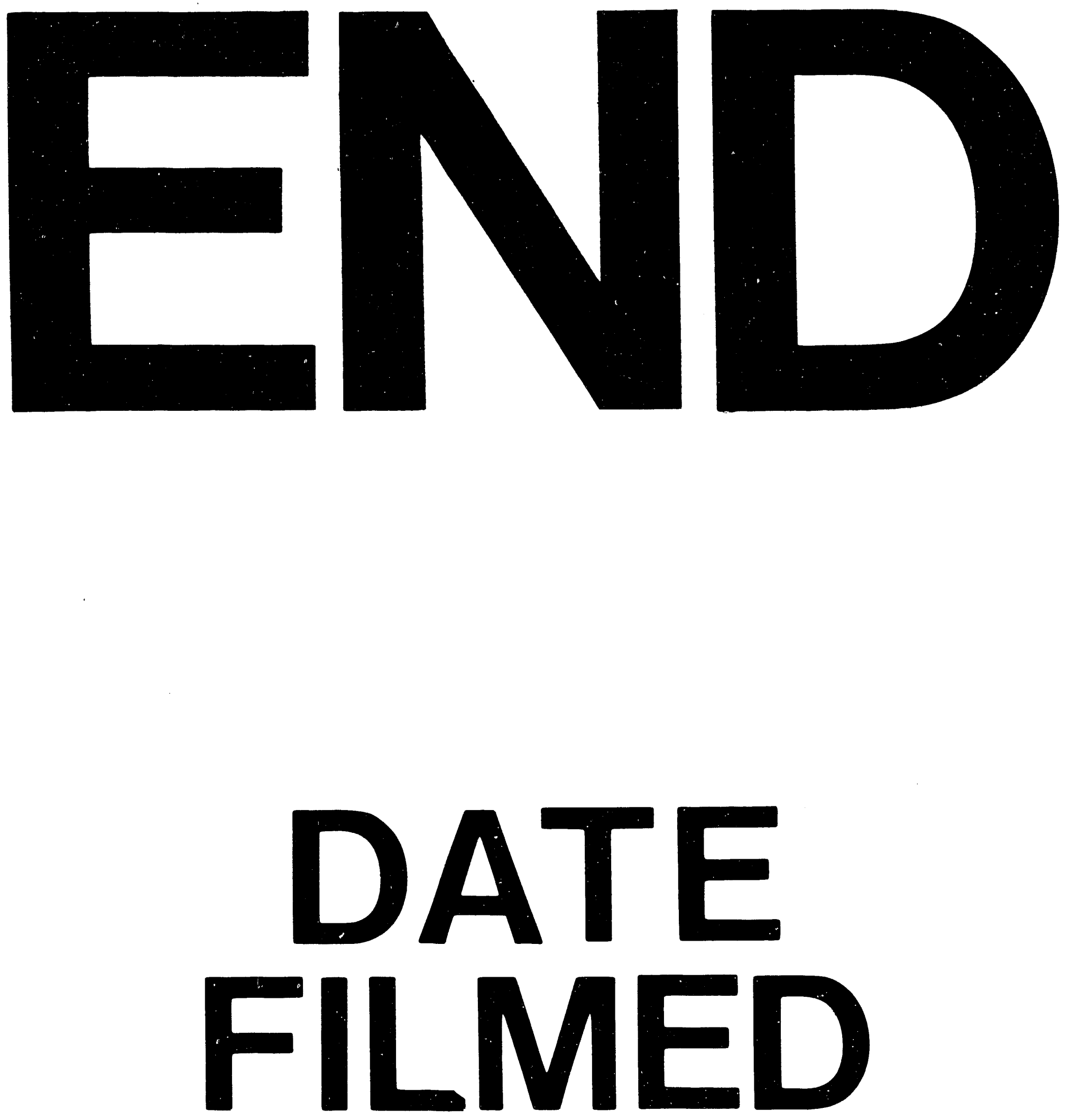

\rfloor

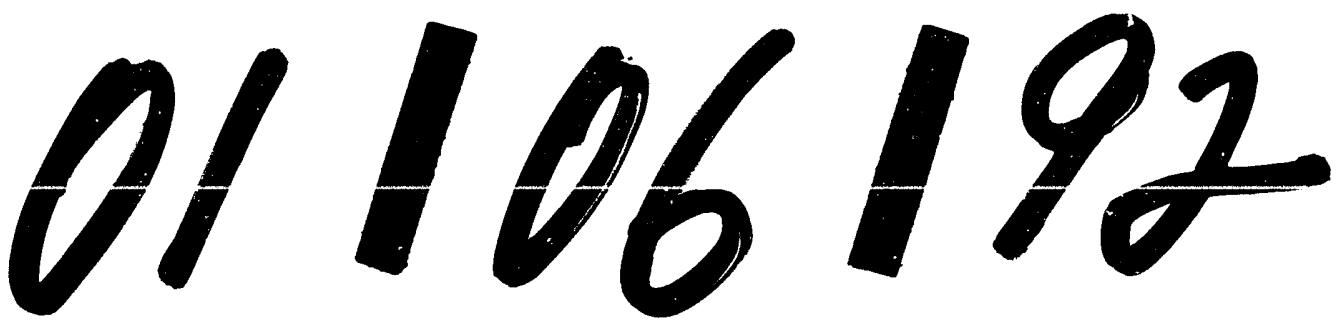


